\title{
Analisis Gaya Geser Dasar Seismik Berdasarkan SNI-03-1726- 2002 Dan SNI 1726:2012 Pada Struktur Gedung Bertingkat
}

\author{
Besty Afriandini ${ }^{1}$, Dani Nugroho Saputro ${ }^{1}$ \\ ${ }^{1}$ Program Studi Teknik Sipil, Fakultas Teknik dan Sains, Universitas Muhammadiyah Purwokerto
}

\section{Informasi Makalah}

Dikirim, 2 Oktober 2018

Direvisi, 17 Oktober 2018

Diterima, 23 Oktober 2018

\section{Kata Kunci:}

gaya geser dasar seismik simpangan antar lantai tingkat SNI 03-1726-2002

SNI 1726:2012

\begin{abstract}
INTISARI
Untuk menanggulangi kerusakan dan keruntuhan bangunan akibat gempa bumi yang sering terjadi, di Indonesia sendiri terdapat peraturan yang mengatur tentang tata cara perencanaan ketahanan terhadap gempa, yaitu yang termuat dalam SNI SNI 1726:2012 yang menggantikan peraturan sebelumnya yaitu SNI 03-1726-2002. Penelitian ini bertujuan untuk mengetahui sejauh mana pengaruh perubahan peraturan yang mengatur ketahanan terhadap gempa di Indonesia dari SNI 03-1726-2002 menjadi SNI 1726:2012, terhadap gaya geser dasar seismik dan simpangan antar lantai. Penelitian ini dilakukan pada model struktur gedung beton bertulang bertingkat tujuh dengan analisis 3D yang diletakan pada 6 ibukota provinsi di pulau Jawa yang rawan gempa yaitu kota Jakarta, Banten, Bandung, Semarang, Yogyakarta, dan Surabaya dengan jenis tanah sedang (SD). Metode analisis menggunakan statik ekivalen dan dilakukan dengan bantuan software SAP. Hasil analisis menunjukan nilai gaya geser dasar seismik dan simpangan antar lantai yang terjadi di 6 lokasi yang ditinjau, akibat beban gempa rencana berdasarkan SNI 1726:2012 lebih besar dibandingkan dengan SNI 03-1726-2002.
\end{abstract}

\section{Keyword:}

base shear

SNI 03-1726-2002

SNI 1726:2012

story drift

\begin{abstract}
The standard about Planning Procedures of Earthquake Resistance for Building Structure and Non-Building Structure in Indonesia, is SNI 1726:2012 that officially replaces the previosly applicable standard, is SNI 03:1726:2002. The research purpose was to determine the influence of the changes of the standar SNI 03-1726-2002 became SNI 1726:2012, toward base shear and story drift. The object of research is 3Dimension model of frame concrete structure and consist of 7 storey, placed on six capital of the province of Java Island that is Jakarta, Banten, Bandung, Semarang, Yogyakarta, and Surabaya with SD soil. The structure is modeled use software SAP and calculating with static equivalent analysis. The analysis result show that from six observed location, the value of base shear and story drift based on SNI 1726:2012 is bigger than SNI 03-1726-2002.
\end{abstract}

\section{Korespondensi Penulis:}

Penulis Ke-1

Program Studi Teknik Sipil

Universitas Muhammadiyah Purwokerto

Jl. Raya Dukuh Waluh, PO BOX 202 Purwokerto 53182 Telp. (0281) 636751

Email: bestyafriandini24@gmail.com

\section{PENDAHULUAN}

Indonesia adalah salah satu negara yang memilik intensitas yang tinggi terhadap kejadian gempa bumi. Getaran di permukaan bumi akibat gempa bumi tersebut akan mengakibatkan kerusakan bahkan keruntuhan pada struktur bangunan bertingkat yang sangat membahayakan yang dapat menimbulkan korban 
jiwa. Untuk menanggulangi kerusakan dan keruntuhan bangunan akibat gempa bumi yang sering terjadi, di Indonesia sendiri terdapat peraturan yang mengatur tentang tata cara perencanaan ketahanan terhadap gempa, yaitu yang termuat dalam SNI 03-1726-2002 tentang Standar Perencanaan Ketahanan Gempa untuk Struktur Bangunan Gedung. Namun setelah 10 tahun berjalan, tata cara ini diubah seiring dengan keluarnya peraturan baru yang termuat dalam SNI 1726:2012 tentang Tata Cara Perencanaan Ketahanan Gempa untuk Struktur Bangunan Gedung dan Non Gedung. Peraturan gempa tahun 2002 didasarkan pada gempa rencana dengan periode ulang 500 tahun (probabilitas kejadian 10\% dalam kurun waktu 50 tahun) [1], sedangkan peraturan gempa 2012 dibuat berdasarkan gempa rencana dengan periode ulang 2.500 tahun (probabilitas kejadian 2\% dalam kurun waktu 50 tahun) [2], sehingga nampak terjadi perubahan yang cukup signifikan, ditinjau dari beban gempa rencana yang harus diberikan pada struktur. Meskipun terjadi perubahan gempa rencana, tidak selalu lokasi dengan tingkat resiko gempa tinggi menurut SNI 2002 mengalami kenaikan respon spektranya pada SNI 2012 [3]. Penelitian ini dilakukan pada model struktur gedung beton bertulang bertingkat tujuh dengan analisis 3D yang diletakan pada 6 ibukota provinsi di pulau Jawa yang rawan gempa yaitu Jakarta, Banten, Bandung, Semarang, Yogyakarta, dan Surabaya dengan kondisi tanah sedang (SD). Metode analisis menggunakan statik ekivalen dan dilakukan dengan bantuan software SAP[4][5].

\section{METODOLOGI PENELITIAN}

Pada penelitian ini analisis dilakukan pada model struktur beton bertulang 7 lantai dengan analisis 3D menggunakan bantuan software SAP v.14. Dimensi balok 300x500 mm, kolom 500x500, tebal pelat 100 $\mathrm{mm}$ dan $120 \mathrm{~mm}$. Model struktur tersebut diletakan pada 6 wilayah gempa yang berbeda yaitu Jakarta, Banten, Bandung, Semarang, Yogyakarta, dan Surabaya dengan kondisi tanah sedang (SD), yang dianggap mewakili karakteristik tanah di ke enam lokasi tersebut. Pemodelan penampang kolom dan balok pada penelitian ini tidak memeperhitungkan retak sehingga momen inersia efektif tidak mengalami reduksi atau momen inersia utuh. Hal tersebut bertujuan untuk mengetahui waktu getar alami dan beban gempa nominal yang terjadi pada struktur. Model struktur tersebut diletakan pada 6 lokasi yaitu Jakarta, Banten, Bandung, Semarang, Yogyakarta, dan Surabaya dengan kondisi tanah sedang (SD). Dianggap 6 lokasi tersebut yang merupakan ibukota di pulau Jawa, dapat mewakili kondisi beban gempa lemah, sedang, dan kuat. Sehingga dengan variasi tersebut kemudian diperoleh 12 kemungkinan beban gempa yang dinyatakan dalam bentuk grafik respon spektrum. Untuk respon spektrum desain dilakukan berdasarkan SNI 03-1726-2002 dan SNI 1726-2012. Perhitungan statik ekivalen berdasarkan SNI 03-1726-2002 meliputi wilayah gempa, jenis tanah, koefisien seismik, faktor keutamaan gempa, dan faktor reduksi. Sedangkan berdasarkan SNI 1726:2012 datadata yang dibutuhkan meliputi kategori resiko, kelas situs, nilai parameter $S_{s}$ dan $S_{1}$ berdasarkan peta gempa, sistem penahan gaya, dan tipe struktur. Data-data tersebut kemudian diinputkan ke pemodelan dengan menggunakan aplikasi SAP 200. Keluaran dari perhitungan menggunakan aplikasi SAP 2000 berupa data waktu getar $(\mathrm{T})$, gaya geser dasar seismik (V), dan nilai translasi arah horisontal $\left(\delta_{\mathrm{xe}}\right)$, kemudian dibandingkan dengan syarat batasan-batasan pada SNI 03-1726-2002 dan SNI 1726:2012.

\section{HASIL DAN PEMBAHASAN}

\section{Pemodelan Struktur}

Pemodelan struktur dilakukan dengan menggunakan software SAP 2000 dengan input berupa data konfigurasi struktur, mutu beton $\left(\mathrm{f}_{\mathrm{c}}{ }^{\prime}\right)=25 \mathrm{MPa}$, mutu baja $\left(\mathrm{f}_{\mathrm{y}}\right)=400 \mathrm{MPa}$, dan modulus elastis beton $\left(\mathrm{E}_{\mathrm{c}}\right)=$ $21019039 \mathrm{~kg} / \mathrm{cm}^{2}$ dan modulus elastisitas baja $\left(\mathrm{E}_{\mathrm{s}}\right)=200000 \mathrm{MPa}$. Model struktur tersebut diletakan pada 6 lokasi yang berbeda yaitu Jakarta, Banten, Bandung, Semarang, Yogyakarta, dan Surabaya dengan kondisi tanah sedang (SD). Berdasarkan SNI 1726-2002 6 lokasi tersebut berada pada daerah wilayah gempa 2, 3, dan 4. Berdasarkan SNI 1726-2012 penentuan parameter percepatan tanah diperoleh dari data www.puskim.pu.go.id . 


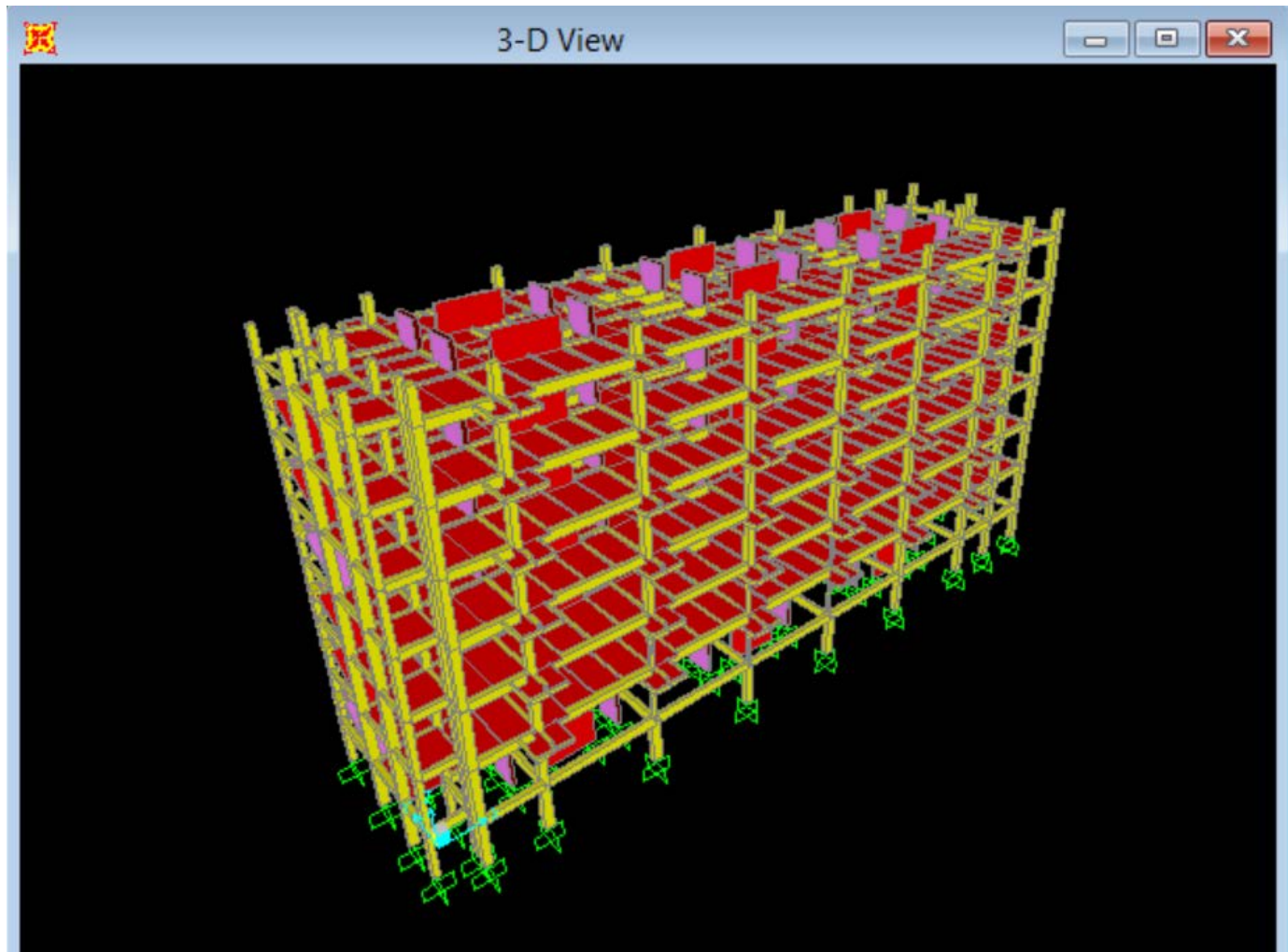

\section{Respon Spektrum}

Gambar 1 Pemodelan Struktur

Respon spektrum desain yang dihasilkan dari perhitungan berdasarkan SNI 1726-2002 dapat dilihat pada grafik di bawah ini. Pada SNI 1726-2002 grafik respon spektrum dibedakan berdasarkan daerah wilayah gempa. Untuk daerah wilayah gempa Banten, Jakarta, dan Bandung adalah 4, untuk Semarang dan Surabaya adalah 2, dan Yogyakarta adalah 3. Dari 6 lokasi tersebut tergolong dalam 3 daerah wilayah gempa yaitu 2, 3, dan 4, sehingga dihasilkan 3 respon spektrum desain. Pada Gambar 2, grafik respon spektrum desain tertinggi yaitu di wilayah Banten, Jakarta, dan Bandung. Kemudian di ikuti oleh wilayah Semarang dan Surabaya, dan yang terendah adalah Yogyakarta.

\section{SPEKTRA RESPON TANAH SEDANG SNI 1726 - 2002}

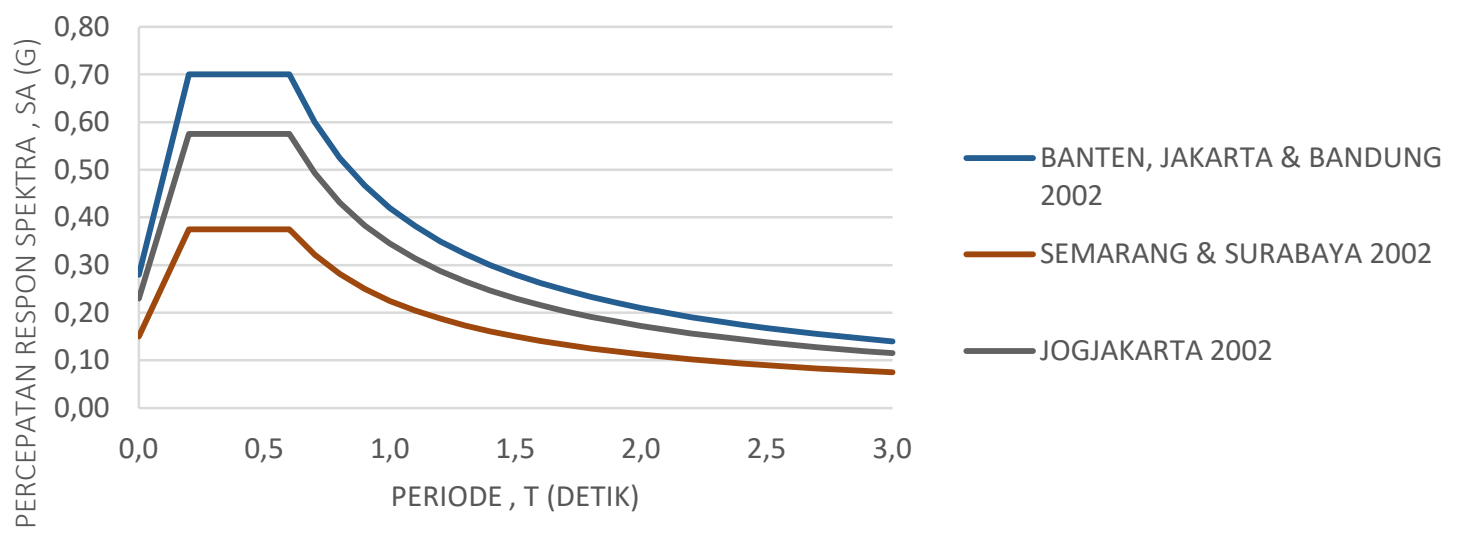

Gambar 2 Respon Spektrum Desain SNI 1726-2002

Respon spektrum desain yang dihasilkan dari perhitungan berdasarkan SNI 1726-2012 dapat dilihat pada grafik di bawah ini. Pada SNI 1726-2012 perhitungan respon spektrum desain didasarkan data parameter percepatan tanah (Ss dan S1) yang dapat diperoleh dari www.puskim.pu.go.id, dimana situs resmi dari 
Kementrian Pekerjaan Umum tersebut berdasarkan dari data peta gempa 2010. Pada gambar di atas wilayah gempa dengan respon spektrum tertinggi adalah Bandung, kemudian diikuti oleh Yogyakarta, Semarang, Banten, Surabaya dan Jakarta, berbeda dengan respon spektrum SNI 1726-2002.

\section{SPEKTRA RESPON TANAH SEDANG SNI 1726}

\section{2}

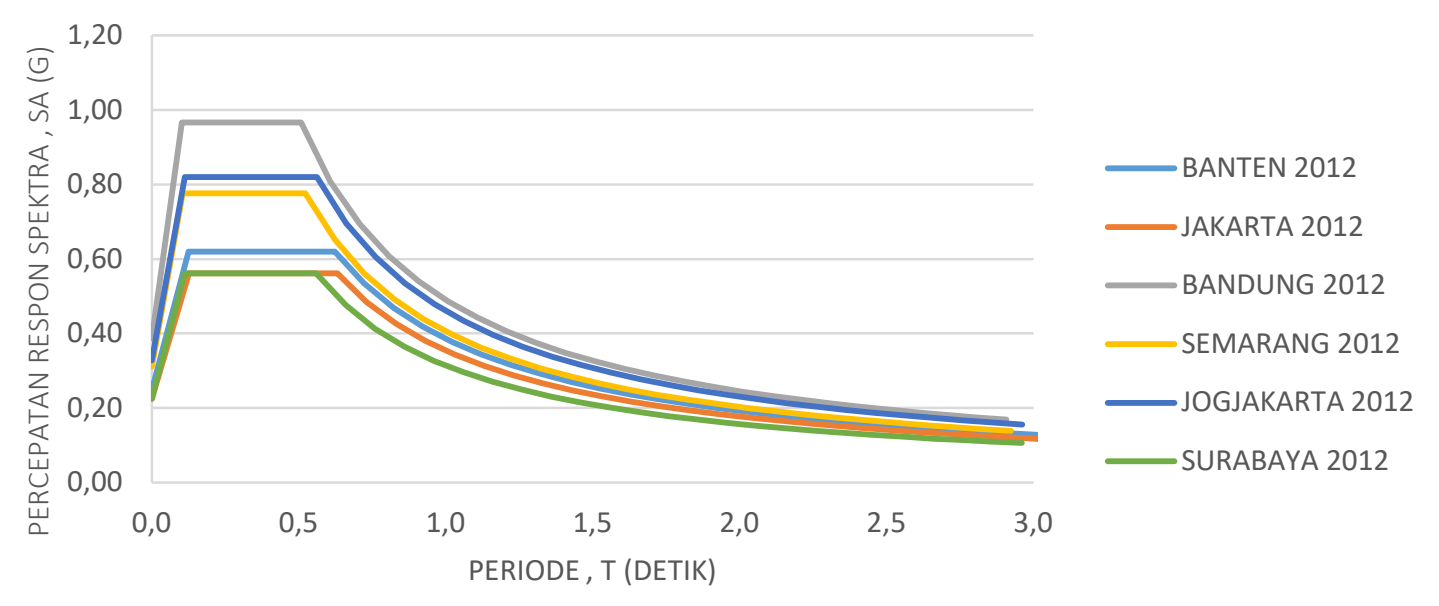

Gambar 3 Respon Spektrum Desain SNI 1726-2012

Perbedaan tersebut dapat terjadi dikarenakan pada SNI 1726:2012 digunakan peta-peta gempa yang baru dalam pembagian koefisien seismiknya, dibandingkan dengan SNI 03-1726-2002 yang hanya membagi kedalam 6 wilayah gempa. Tetapi tidak semua lokasi pada peta-peta gempa yang digunakan pada SNI 1726:2012 menunjukan nilai koefisien seismik dan percepatan respon spektra yang lebih tinggi dibandingkan dengan nilai C pada SNI 03-1726-2002. Kondisi respon spektrum yang berbeda-beda akan menghasilkan nilai koefisien gempa dasar $\mathrm{C}_{\mathrm{d}}$ yang berbeda-beda pula, sehingga akan dihasilkan gaya geser dasar seismik akibat gaya gempa rencana yang berbeda bergantung dari percepatan respon spektra lokasi dimana struktur berdiri.

\section{Gaya Geser Dasar Seismik}

Hasil perhitungan dan analisis pemodelan, gaya geser dasar seismik pada struktur untuk setiap kota yang ditinjau berdasarkan SNI 03-1726-2002 dan SNI 1726:2012 dapat dilihat pada tabel di bawah ini.

Tabel 1 Gaya Geser Dasar Seismik

\begin{tabular}{lcc}
\hline \multirow{2}{*}{ KOTA } & \multicolumn{2}{c}{ Gaya Geser Dasar Seismik / V $(\mathrm{kN})$} \\
\cline { 2 - 3 } & SNI 03-1726-2002 & SNI 1726:2012 \\
\hline BANTEN & 4312,81 & 5319,76 \\
\hline JAKARTA & 4312,81 & 4924,08 \\
\hline BANDUNG & 4312,81 & 6814,57 \\
\hline SEMARANG & 2361,78 & 5627,52 \\
\hline YOGYAKARTA & 3388,64 & 6374,92 \\
\hline SURABAYA & 2361,78 & 4352,53 \\
\hline
\end{tabular}

Sumber : Hasil Perhitungan

Berdasarkan data pada tabel tersebut, gaya geser dasar seismik pada struktur yang berada di 6 kota tersebut dengan persamaan SNI 1726:2012, menunjukan nilai yang lebih besar dibandingkan dengan menggunakan persamaan SNI 03-1726-2002. 


\section{Simpangan Antar antai Tingkat}

Nilai simpangan antar lantai hasil analisis berdasarkan beban gempa rencana SNI 03-1726-2002 dan SNI 1726:2012 dapat dilihat pada tabel 5.3 dan 5.4 di bawah ini :

Tabel 2 Nilai Simpangan Antar Lantai berdasarkan SNI 03-1726-2002

\begin{tabular}{cccc}
\hline \multirow{2}{*}{ LANTAI } & \multicolumn{3}{c}{ SIMPANGAN SNI 03-1726-2002 $(\Delta)(\mathrm{mm})$} \\
\cline { 2 - 4 } & $\begin{array}{c}\text { BANTEN, JAKARTA, } \\
\text { BANDUNG }\end{array}$ & $\begin{array}{c}\text { SEMARANG, } \\
\text { SURABAYA }\end{array}$ & YOGYAKARTA \\
\hline 7 & 9,167 & 9,533 & 6,967 \\
\hline 6 & 10,267 & 11,733 & 8,067 \\
\hline 5 & 11,367 & 13,200 & 8,800 \\
\hline 4 & 11,367 & 13,933 & 9,167 \\
\hline 3 & 11,000 & 13,200 & 8,433 \\
\hline 2 & 8,067 & 10,267 & 6,233 \\
\hline 1 & 2,567 & 3,300 & 2,200 \\
\hline
\end{tabular}

Sumber : Hasil Perhitungan

Nilai simpangan maksimum untuk semua kota terjadi pada lantai ke-4, dan nilai simpangan pada lantai ke-4 terbesar terjadi di kota Semarang dan Surabaya yaitu sebesar 13,933 mm. Batasan nilai simpangan $\left(\Delta_{\mathrm{a}}\right)$ yang diatur pada SNI 03-1726-2002 adalah sebesar 30 mm.

Tabel 3 Nilai Simpangan Antar Lantai berdasarkan SNI 1726:2012

\begin{tabular}{ccccccc}
\hline \multirow{2}{*}{ LANTAI } & \multicolumn{7}{c}{ SIMPANGAN SNI 1726:2012 (mm) } \\
\cline { 2 - 7 } & BANTEN & JAKARTA & BANDUNG & SEMARANG & YOGYAKARTA & SURABAYA \\
\hline 7 & 9,167 & 8,800 & 12,100 & 9,533 & 11,367 & 7,700 \\
\hline 6 & 11,000 & 9,900 & 13,933 & 11,733 & 12,833 & 8,800 \\
\hline 5 & 12,467 & 11,367 & 15,767 & 13,200 & 15,033 & 10,267 \\
\hline 4 & 13,200 & 12,467 & 16,867 & 13,933 & 15,767 & 10,633 \\
\hline 3 & 12,467 & 11,733 & 16,133 & 13,200 & 15,033 & 10,267 \\
\hline 2 & 9,533 & 8,800 & 12,467 & 10,267 & 11,733 & 8,067 \\
\hline 1 & 3,300 & 2,933 & 4,033 & 3,300 & 3,667 & 2,567 \\
\hline
\end{tabular}

Sumber : Hasil Perhitungan

Untuk nilai simpangan antar lantai tingkat hasil analisis dengan beban gempa rencana berdasarkan SNI 1726:2012 menunjukan nilai maksimum pada lantai ke-4 untuk semua kota. Nilai simpangan lantai ke-4 yang terbesar berada di kota Bandung, yaitu sebesar 16,867 mm. Batasan nilai simpangan ( $\Delta_{\mathrm{a}}$ ) yang diatur pada SNI 1726:2012 adalah sebesar 30,679 mm.

Sehingga simpangan antar lantai tingkat yang terjadi pada struktur akibat beban gempa rencana SNI 03-17262002 dan SNI 1726:2012 di semua lokasi telah memenuhi syarat. Hal tersebut menunjukan bahwa struktur tersebut masih mampu menahan beban gempa yang terjadi.

Perbandingan nilai simpangan antar lantai yang terjadi pada struktur setelah dibebankan beban gempa rencana berdasarkan SNI 03-1726-2002 dan SNI 1726:2012 pada setiap kota, dapat dilihat pada grafik di bawah ini : 


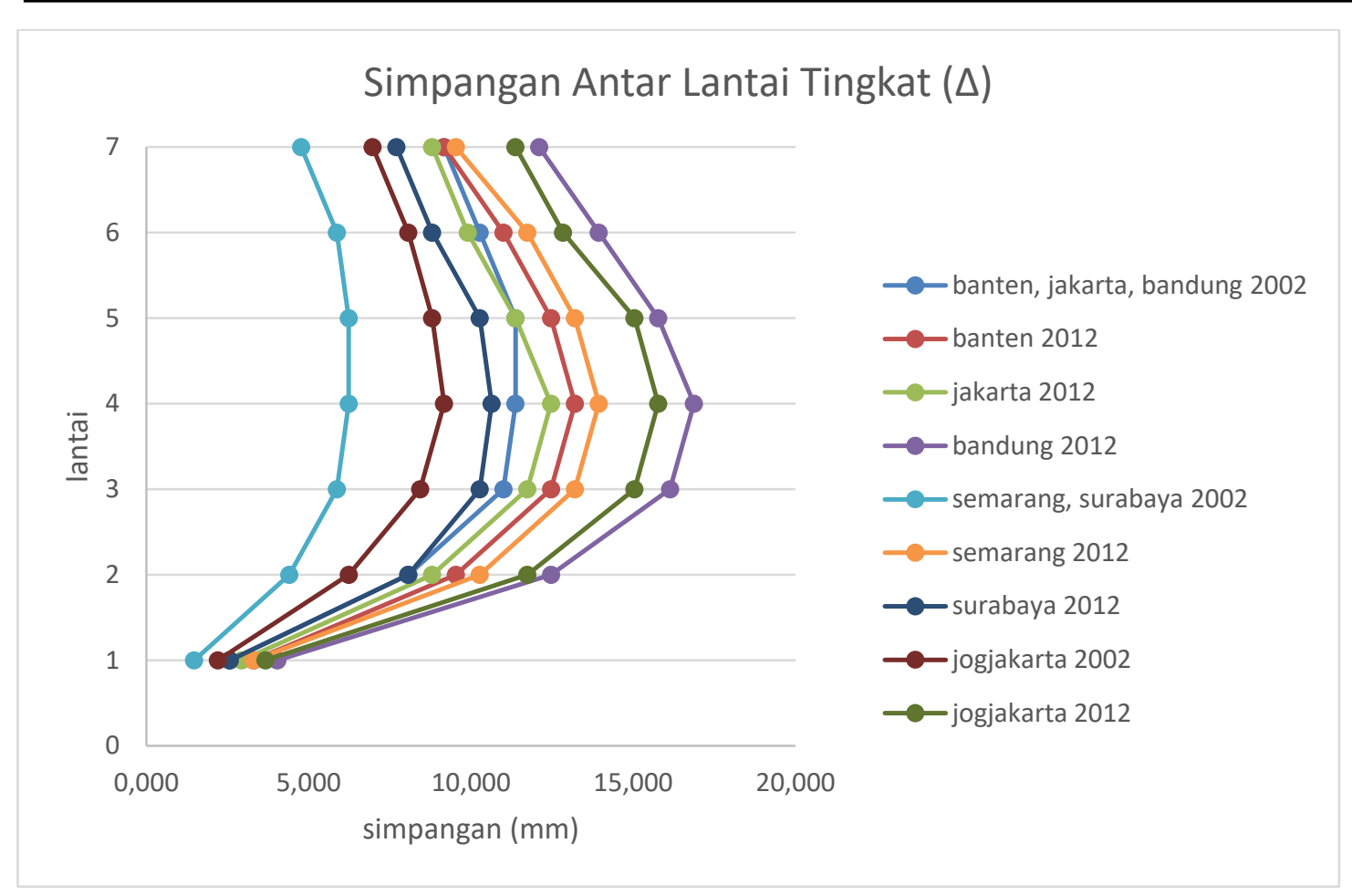

Gambar 4 Simpangan antar lantai tingkat $(\Delta)$

Nilai simpangan antar lantai tingkat yang terjadi pada struktur di setiap kota dengan beban gempa rencana berdasarkan SNI 03-1726-2002 menunjukan nilai yang lebih kecil dibandingkan dengan beban gempa rencana berdasarkan SNI 1726:2012.

\section{KESIMPULAN}

Berdasarkan hasil analisis dan pembahasan, dapat disimpulkan sebagai berikut :

1. Respon spektra desain untuk kota Bandung, Semarang, Yogyakarta, dan Surabaya berdasarkan hasil hitungan dengan persamaan SNI 1726:2012, memiliki nilai yang lebih besar dari percepatan spektra dengan persamaan SNI 03-1726-2002. Menandakan bahwa gaya gempa rencana pada kota Bandung, Semarang, Yogyakarta dan Surabaya berdasarkan SNI 1726:2012 lebih besar dari SNI 03-1726-2002, sehingga bangunan yang sudah dibangun pada kota tersebut menjadi under design.

2. Respon spektra desain kota Banten dan Jakarta berdasarkan persamaan SNI 1726:2012 lebih kecil dari nilai percepatan spektra berdasarkan persamaan SNI 03-1726-2002, menandakan gaya gempa rencana pada kota Banten dan Jakarta berdasarkan SNI 1726:2012 lebih kecil dari SNI 03-17262002.

3. Hasil analisis gaya geser dasar seismik pada struktur yang berada di 6 kota tersebut (Banten, Jakarta, Bandung, Semarang, Yogyakarta dan Surabaya) dengan persamaan SNI 1726:2012, menunjukan nilai yang lebih besar dibandingkan dengan menggunakan persamaan SNI 03-17262002.

\section{UCAPAN TERIMAKASIH}

$\mathrm{XX} \mathrm{XXX}$ 


\section{DAFTAR PUSTAKA}

[1] BSN, 2001, SNI 03-1726-2002, Standar Perencanaan Ketahanan Gempa untuk Struktur Bangunan Gedung, Jakarta.

[2] BSN, 2012, SNI 1726, 2012-Tata Cara Perencanaan Ketahanan Gempa untuk Struktur Bangunan Gedung dan Non Gedung, Jakarta.

[3] Cornelis.Remigildus, et al.,”Analisis Perbandingan Gaya Geser Tingkat, Gaya Geser Dasar, Perpindahan Tingkat dan Simpangan Antar Tingkat Beban Gempa Berdasarkan Peraturan Gempa SNI 1726-2002 dan SNI 1726-2012”, Jurnal Teknik Sipil Vol. III, No.2, September 2014.

[4] Satyarno, Iman., 2012. Belajar SAP 2000. Edisi Kedua. Zamil Publishing. Yogyakarta.

[5] Satyarno, Iman., 2015. Belajar SAP 2000 Analisis Gempa . Cetakan kedua. Zamil Publishing. Yogyakarta. 
